\title{
Ultrastructural characterisation of Marteilia species (Paramyxea) from Ostrea edulis, Mytilus edulis and Mytilus galloprovincialis in Europe
}

\author{
Matt Longshaw $^{1, *}$, Stephen W. Feist ${ }^{1}$, R. Anthony Matthews ${ }^{2}$, Antonio Figueras ${ }^{3}$ \\ ${ }^{1}$ Centre for Environment, Fisheries and Aquaculture Science (CEFAS) Weymouth Laboratory, Barrack Road, \\ The Nothe, Weymouth, Dorset DT4 8UB, United Kingdom \\ ${ }^{2}$ Department of Biological Sciences, University of Plymouth, Drakes Circus, Plymouth, Devon PL4 8AA, United Kingdom \\ ${ }^{3}$ Instituto de Investigaciones Marinas-CSIC, Departmento de Biologìa y Patologìa de Organismos Marinos, \\ Eduardo Cabello 6, 36208 Vigo, Spain
}

\begin{abstract}
A focused ultrastructural study of Marteilia spp. found in cultured Ostrea edulis, Mytilus edulis and Mytilus galloprovincialis from France and Spain was conducted with emphasis placed on haplosporosomes, striated plate-like inclusions and spore wall morphology. Two types of haplosporosome were identified, sphaeroid and oblate, which were common to the parasite in all 3 host species. A total of 492 haplosporosomes were measured; those from the Marteilia sp. in Mytilus spp. were marginally smaller than those in Ostrea edulis. Spore wall morphology was found to vary depending on the state of maturity of the parasite - the more mature the parasite, the thicker the wall surrounding it. It is suggested that the current criteria used to distinguish $M$. maurini from $M$. refringens are invalid and that $M$. maurini was relegated to a junior synonym of $M$. refringens.
\end{abstract}

KEY WORDS: Marteilia refringens $\cdot$ Marteilia maurini $\cdot$ Ultrastructure

Resale or republication not permitted without written consent of the publisher

\section{INTRODUCTION}

The paramyxeans are a group of protistan parasites that includes several species known to cause significant disease in cultured marine bivalve molluscs. Currently the phylum Paramyxea consists of 2 classes, Marteiliidea with 3 genera, Marteilia (Grizel et al., 1974) Perkins, 1976, Paramarteilia Ginsburger-Vogel \& Desportes, 1979 and Marteilioides (Comps et al., 1986) Anderson \& Lester, 1992; and Paramyxidea with a single genus, Paramyxa Chatton, 1911. These organisms, particularly those in the genera Marteilia and Marteilioides, have been extensively studied due to their detrimental effect on commercially exploited bivalves. One such species, Marteilia refringens (Grizel et al., 1974) Perkins, 1976, has caused recurring mortalities

*E-mail: m.longshaw@cefas.co.uk in flat oysters Ostrea edulis L. from France, Spain and Portugal since its discovery in 1968. The antipodean equivalent, Marteilia sydneyi Perkins \& Wolf, 1976, the causative agent of QX disease, is responsible for mortalities of Saccostrea commercialis in Queensland, Australia. In addition, Comps et al. (1982) described $M$. maurini from Mytilus galloprovincialis Lmk. collected in Venice Lagoon and imported into France. It was subsequently reported in $M$. edulis collected from 3 bivalve culture areas in Brittany, northern France (Auffret \& Poder 1985). The genus Marteilioides includes 2 recognised pathogens, $M$. chungmuensis Comps et al., 1986 from Japanese and Korean Crassostrea gigas, and M. branchialis Anderson \& Lester, 1992 in S. commercialis from Australia. These pathogens cause focal lesions, reduced growth and frequently death.

There is concern about the translocation of these pathogens to naive, susceptible stocks; thus, strict guidelines have been adopted to ensure that only 
healthy animals are transferred to areas where the diseases are known to be absent. This is the case with Marteilia refringens in Europe. The European Community Council Directive 91/67 (OJ No L46 19.2.1991) includes $M$. refringens in annex A, list II, as a serious pathogen of the susceptible species Ostrea edulis. The diagnosis of the 2 species of Marteilia found in Europe ( $M$. refringens and $M$. maurini) currently requires analysis of the ultrastructural characteristics and consideration of the host specificity (Grizel 1974, Comps et al. 1982). Indeed, the only ultrastructural features selected by Comps et al. (1982) to distinguish the 2 species were subtle differences in haplosporosome shape and the 'existence of a multimembranous envelope next to the spore wall'.

The recent discovery of Marteilia refringens in Mytilus galloprovincialis (Villalba et al. 1993, Robledo \& Figueras 1995) has raised some doubt that Marteilia maurini, which was described as the only Marteilia species parasitizing mussels, is a distinct species from M. refringens. Experimental transmission of M. refringens between members of the same or differing host species has been unsuccessful, although it has been attempted in a number of experiments under differing conditions (Figueras \& Robledo 1993, Berthe et al. 1998).

Because flat oysters cultured in Europe suffer mortalities as a result of infections with Marteilia refringens and the questionable taxonomic status of the Marteilia sp. reported from mussels Mytilus edulis (described as M. maurini Comps et al., 1982) which has not been associated with mortalities, it is important to establish whether one or several European Marteilia species exist.

The objective of the current study was to re-evaluate the taxonomic features used to discriminate the Marteilia species in Ostrea edulis, Mytilus galloprovincialis and Mytilus edulis.

\section{MATERIALS AND METHODS}

Ostrea edulis and Mytilus edulis were collected from France in February and April 1995. These were screened for infections with Marteilia spp. by examining air-dried, methanol fixed, digestive gland imprints stained with methylene blue. Intensity of infection was classified as light (+), medium (++) and heavy (+++). Digestive gland material from parasitised specimens was fixed in $2.5 \%$ gluteraldehyde in $0.1 \mathrm{M}$ sodium cacodylate buffer for $24 \mathrm{~h}$ at $4^{\circ} \mathrm{C}$, washed twice in buffer, post fixed in $1 \%$ osmium tetroxide in $0.1 \mathrm{M}$ buffer for $1 \mathrm{~h}$ and again rinsed in buffer. Samples were dehydrated through graded alcohols and propylene oxide and embedded in resin.
Similarly, samples of infected Mytilus galloprovincialis were collected in Ria de Vigo (North West Spain) during 1994. This material included infected digestive glands and Marteilia maurini from M. galloprovincialis purified as described by Robledo et al. (1995) embedded as above.

Semi-thin sections were cut at $1 \mu \mathrm{m}$ thickness and stained with toluidine blue. Examination of these at light microscope level enabled the selection of heavily infected digestive glands containing a wide range of development stages. Ultrathin sections (80 to $85 \mathrm{~nm}$ ) were cut on a Leica Ultracut $\mathrm{S}$, floated onto copper EM grids and stained with uranyl acetate/Fahmys lead citrate (Lewis \& Knight 1977). Stained sections were examined using a JEOL 1210 transmission electron microscope.

A limited ultrastructural investigation was undertaken of both Marteilia refringens from Ostrea edulis and Marteilia maurini from Mytilus edulis and Mytilus galloprovincialis. Particular attention was given to selected organelles, namely haplosporosomes and striated plate-like inclusions and to the spore wall, as these have previously been used for species discrimination by other workers. Measurements of selected organelles were done directly on the TEM using inbuilt calibrated image measuring software. A total of 492 haplosporosomes were examined including 243 from $M$. refringens and 249 from $M$. maurini. The terminology of Perkins (1979) was adopted in describing the haplosporosome and all other structures examined.

\section{RESULTS}

Fourteen infected Mytilus edulis from France were used in the ultrastructural analysis. Of these, 5 were classed as lightly infected, 5 were medium infected and 4 were heavily infected. Additionally, 6 Ostrea edulis were used in ultrastructural studies; of these, 2 had a medium infection level and 4 were heavily parasitised.

Ultrastructural studies confirmed the presence of stages previously described by Perkins (1976). The earliest identifiable stage was a primary cell with a single secondary cell within it (Fig. 1A). The parasite then proceeded through a series of divisions to produce 8 presporangia or secondary cells (Fig. 1B). After division these presporangia contained 4 spore primordia (tertiary cells), each of which cleaved internally to produce mature spores. The mature spore consisted of 3 sporoplasms, one inside the other (outermost, intermediate and innermost) (Fig. 1C). The outermost sporoplasm contained haplosporosomes. In mature Marteilia refringens the haplosporosomes were sphaeroid or oblate (Fig. 1D), as was the case with M. maurini, 

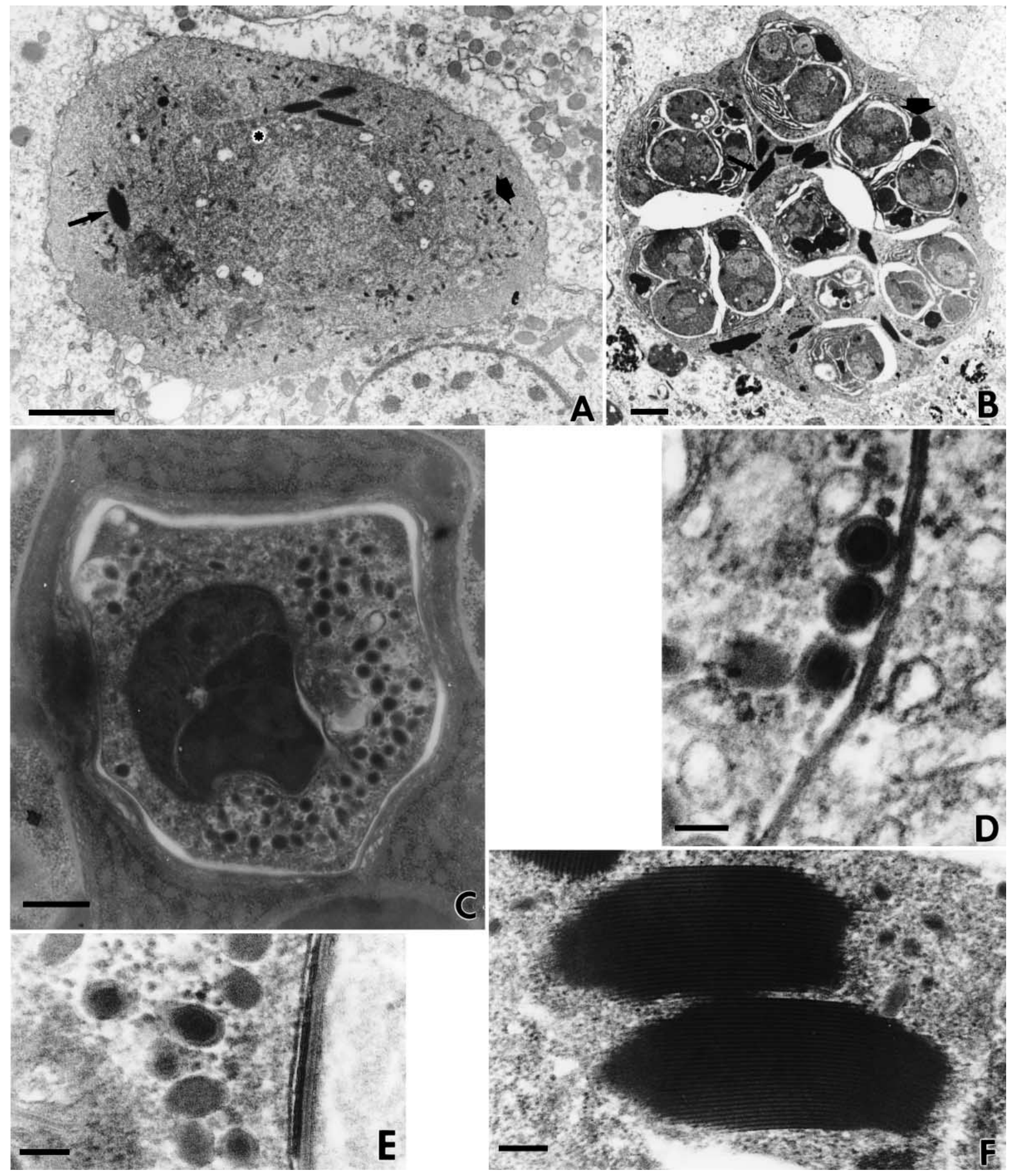

Fig. 1. (A) Primary cell of Marteilia sp. containing a single secondary cell within it. Note numerous mitochondria (*) within secondary cell, and striated plate-like inclusions $(\rightarrow$ ) and haplosporosomes $(\bullet)$ in the cytoplasm of the primary cell. (B) Sporangiosorus with 8 presporangia and immature spores. Numerous striated plate-like inclusions $(\rightarrow)$ are visible in the cytoplasm of the sporangiosorus and refringent granules ( are visible within presporangia. (C) Mature spore of M. refringens from oysters showing 3 sporoplasms; thickened wall characteristic of maturity and sphaeroid haplosporosomes. (D) Sphaeroid haplosporosomes of M. refringens from oysters clearly showing medulla and cortex. (E) Oblate sphaeroid haplosporosomes of Marteilia sp. from mussels. Note cortex and medulla and thickening of cell wall. (F) Striated plate-like inclusions in cytoplasm of developing sporangiosorus. Scale bars: $(A)=1 \mu m_{i}(B)=2 \mu m_{i}(C)=500 \mathrm{~nm}_{i}(D)=100 \mathrm{~nm}_{i}(E) \&(F)=200 \mathrm{~nm}$ 
Table 1. Measurements of haplosporosomes from Marteilia spp. parasitic in Ostrea edulis, Mytilus edulis and M. galloprovincialis taken during the current study and from published data. All measurements are in $\mathrm{nm}$

\begin{tabular}{|lllll|}
\hline Species & Host & $\begin{array}{l}\text { Oblate haplosporosomes } \\
\text { Length } \times \text { Width }(\text { mean) }\end{array}$ & $\begin{array}{l}\text { Sphaeroid haplosporosomes } \\
\text { Length } \times \text { Width (mean) }\end{array}$ & Source \\
\hline M. refringens & O. edulis & $106-191(137) \times 71-117(95)$ & $87-137(111)$ & Present study \\
M. refringens & O. edulis & $230 \times 140$ & - & Grizel et al. (1974) \\
M. refringens & O. edulis & $175-203(189) \times 71-158(111)$ & $98-196(113)$ & Perkins (1976, 1979) \\
Marteilia sp. & M. edulis & $107-296(230) \times 41-86(65)$ & $72-141(90)$ & Present study \\
Marteilia sp. & M. edulis & $260 \times 120$ & $130-160$ & Auffret \& Poder (1985) \\
Marteilia sp. & M. galloprovincialis & $92-312 \times 40-150$ & - & Villalba et al. (1993) \\
Marteilia sp. & M. galloprovincialis & $130-400 \times 130-200$ & $80-200$ & Robledo \& Figueras (1995) \\
Marteilia sp. & M. galloprovincialis & $230-320 \times 70-90$ & $80-120$ & Comps et al. (1982) \\
\hline
\end{tabular}

although the latter were marginally smaller (Fig. 1E) (Table 1). There was some variation in the structure of the spore wall associated with the stage of development. With the breakdown of haplosporosome and sporangiosorus cytoplasm there was an increasing build up of myelin whorls around the spore.

Striated plate-like inclusions (Fig. 1F) were only found in those stages of development which contained haplosporosomes, including earlier stages of the sporangiosorus (primary cell) and in stages containing spores. They consisted of alternating electron-dense and electron-lucent layers with a regular periodicity of $24.64 \mathrm{~nm} \pm 2.45$ (22.17 to $29.75 \mathrm{~nm}$ ) for Marteilia maurini and $23.31 \mathrm{~nm} \pm 3.02$ (21.96 to $28.04 \mathrm{~nm}$ ) for M. refringens.

\section{DISCUSSION}

The present study challenges current established criteria (Perkins 1976, Perkins \& Wolf 1976, Comps et al. 1982, Auffret \& Poder 1985) for the identification of species of Marteilia sp. Our measurements of haplosporosomes from Marteilia spp. in the different host species have shown considerable variation and overlap in size ranges as can be seen when comparing the results to previous studies. Consequently, haplosporosome morphology should be considered to be highly pleomorphic and therefore not a reliable means of defining species. It is believed that the use of haplosporosome measurements as a diagnostic tool to discriminate between species is problematic. Variations which may result from use of different processing, fixation and viewing methods may be expected to be as great or greater the size difference recorded by various authors. Similarly, the use of striated plate-like inclusions can equally be considered to be of no value in separating Marteilia sp. obtained from the 3 host species, as no differences were detected in their shape, pattern of striations or periodicity.
Finally, the use of spore wall ultrastructure was also considered as a possible taxonomic criterion. Perkins \& Wolf (1976) stated that the spore wall of Marteilia sydneyi was surrounded by a heavy layer of concentric membranes, which was 'occasionally' present in $M$. refringens. $M$. maurini was also separated from $M$. refringens on the basis that these concentric membranes were absent in M. maurini (Comps et al. 1982). In the course of this study, it was found that in mature $M$. refringens specimens, i.e. those with noticeable breakdown of the sporangiosoral cytoplasm or mature haplosporosomes (those clearly showing medulla and cortex), there was a build-up of concentric membranes around the spore wall. This was also true for M. maurini. Spore wall thickness can therefore only be of taxonomic value when measured on a mature spore. The available information is of limited use because of the lack of details, in particular about maturity, provided in several previous studies. It is suggested that for speciation to be determined at the ultrastructural level, all life stages should be examined, particularly the later spore stages in the host.

Higher level structural criteria, discernable by light microscopy, were used by Perkins \& Wolf (1976) to separate Marteilia sydneyi from M. refringens, namely that sporangiosori contained 8 to 16 sporangia, compared with 8 for $M$. refringens, and sporangia contain 2 to 3 rather than 4 spores (Perkins \& Wolf 1976) (see Table 2). Using these criteria, it would be impossible to separate $M$. maurini from $M$. refringens as both 'species' of the parasite have 8 sporangia which contain 4 spores.

Based on the material examined in this study and the observation of pleomorphic haplosporosomes and variability of spore wall morphology, it is considered that Marteilia maurini from Mytilus spp. cannot be reliably separated from Marteilia refringens from Ostrea edulis using ultrastructural criteria. Spore wall morphology, and therefore wall thickness, appears to be dependent on the degree of maturation of the spores and sporan- 
Table 2. Number of secondary and tertiary cells and sporoplasms in tertiary cells of paramyxean genera and species. ND = no data

\begin{tabular}{|lcccl|}
\hline Species & $\begin{array}{c}\text { No. of } \\
\text { secondary cells }\end{array}$ & $\begin{array}{c}\text { No. of } \\
\text { tertiary cells }\end{array}$ & $\begin{array}{c}\text { No. of } \\
\text { sporoplasm cells }\end{array}$ & $\begin{array}{l}\text { Selected } \\
\text { reference }\end{array}$ \\
\hline Marteilia refringens & 8 & $3-4$ & 3 & Perkins (1976) \\
Marteilia sydneyi & $8-16$ & $2(3)$ & 3 & Perkins \& Wolf (1976) \\
Marteilia lengehi & 8 & $3-4$ & ND & Comps (1976) \\
Marteilia maurini & 8 & 4 & 3 & Comps et al. (1982) \\
Marteilia christenseni & 8 & 1 & 3 & Comps (1985) \\
Marteilioides chungmuensis & $2-3$ & 1 & 3 & Anderson \& Lester (1992) \\
Marteilioides branchialis & $2-6(12)$ & 2 & 2 & Ginsberger-Vogel \& \\
Paramarteilia orchestiae & $1-12$ & 4 & 4 & Desportes (1979a,b) \\
Paramyxa paradoxa & 4 & & & Chatton (1911) \\
\hline
\end{tabular}

giosorus and can therefore not be used as a criterion for the discrimination of species. Haplosporosome size and shape of both species of Marteilia are highly variable. Taking into account the data obtained from previous studies, it is clear that haplosporosome morphology is too inconsistent and with too much overlap in size range between Marteilia spp. in different hosts to provide a robust diagnostic feature. M. maurini was described from Mytilus galloprovincialis collected in Venice Lagoon and imported into France (Comps et al. 1982).

On the basis that there are no reliable features at the light microscope level or at the ultrastructure level, and taking into account an apparent lack of host specificity, we propose that Marteilia maurini be relegated to a junior synonym of $M$. refringens.

Developments in DNA based methods can offer, in some cases, a more objective method of discriminating between putative protistan species compared with the ultrastructural morphological approach (Philippe et al. 1995, Adoutte et al. 1996). In the present case, the attempt to define parasite species based primarily on occurrence in different host species has resulted in attempts to correlate fine morphological differences to support this distinction. As reported here, detailed analysis of these differences do not support this. Two haplosporidians (Haplosporidium nelsoni and $H$. costale) that inhabit the same area and host and have a similar morphology in the plasmodial stage, but different spore stages, were found to be clearly different when their 18S rDNA sequence were compared (Fong et al. 1993, Ko et al. 1995, Stokes et al. 1995). Perkinsus olseni from Australia and P. atlanticus from Portugal are morphologically similar and were found to belong to a single species, but $P$. marinus (found in the USA) was well discriminated from these 2 species (Goggin 1994). It is possible, however, that different analyses of the DNA of $P$. olseni and $P$. atlanticus could show a difference. Although Marteilia refringens and $M$. maurini are here regarded as conspecific based on morpho- logical features, it will be desirable to confirm this using DNA sequence data. In addition, the use of DNA sequences, DNA probes and techniques such as in situ hybridisation in tracking infections in putative alternate hosts and examining parasite maturation will prove invaluable in future studies of this parasite.

Acknowledgements. This work was supported by European Union FAIR contract 94C 85/13.

\section{LITERATURE CITED}

Adoutte A, Germot A, Le Guyader H, Philippe H (1996) Que savons-nous de l'historie évolutive des eucaryotyes? 2. De la diversification des protistes à la radiation des multicellulaires. Méd Sci 12(2):I-XVIII

Anderson TJ, Lester RJG (1992) Sporulation of Marteilioides branchialis n. sp. (Paramyxea) in the Sydney rock oyster, Saccostrea commercialis: an electron microscope study. J Protozool 39(4):502-508

Auffret M, Poder M (1985) Recherches sur Marteilia maurini parasite de Mytilus edulis sur les cotes de Bretagne Nord. Rev Trav Inst Peches Marit 47(1-2):105-109

Berthe FJ, Pernas M, Zerabib M, Haffner P, Thebault A, Figueras AJ (1998) Experimental transmission of Marteilia refringens with special consideration of its life cycle. Dis Aquat Org 43(2):135-144

Chatton E (1911) Sur une cnidospiridie sans cnidoblaste (Paramyxa paradoxa, n.g., n.sp.). C R Acad Sci Paris 152: 631-633

Comps (1976) Marteilia lengehi n.sp., parasite de l'huître Crassostrea cucullata Born. Rev Trav Inst Pêches Marit 40(2):347-349

Comps (1985) Etude morphologique de Marteilia christenseni sp.n., parasite du lavignon Scrobicularia piperata P. (Mollusque pélécypode). Rev Trav Inst Pêches Marit 47(1-2): 99-104

Comps M, Pichot Y, Papagianni P (1982) Recherche sur Marteilia maurini n. sp. parasite de la moule Mytilus galloprovincialis Lmk. Rev Trav Inst Peches Marit 45(3):211-214

Comps M, Park MS, Desportes I (1986) Etude ultrastructurale de Marteilioides chungmuensis n.g., n. sp. parasite des ovocytes de l'huitre Crassostrea gigas Th. Protistologica 22(3):279-285

Figueras A, Robledo JAF (1993) Does the Marteilia present in mussels (Mytilus galloprovincialis) infect flat oysters (Ostrea edulis)? Bull Eur Assoc Fish Pathol 13(3):97-99 
Fong D, Chan MM, Rodriguez R, Chen C, Liang Y, Littlewood T, Ford S (1993) Small subunit ribosomal RNA gene sequence of the parasitic protozoan Haplosporidium nelsoni provides a molecular probe for the oyster MSX disease. Mol Biochem Parasitol 62:139-142

Ginsburger-Vogel T, Desportes I (1979a) Structure and biology of Marteilia sp. in the amphipod, Orchestia gammarellus. Mar Fish Rev 41(1-2):3-7

Ginsburger-Vogel T, Desportes I (1979b) Etude ultrastructurale de la sporulation de Paramarteilia orchestiae gen. n. sp. n. parasite de l'amphipode Orchestia gammarellus Pallas. Protistologica 26(3):390-403

Goggin CL (1994) Variation in the two internal transcribed spacers and 5.8S ribosomal RNA from five isolates of the marine parasite Perkinsus (Protista, Apicomplexa). Mol Biochem Parasitol 65:179-182

Grizel H, Comps M, Bonami JR, Cousserans F, Duthoit JL, Le Pennec MA (1974) Recherche sur l'agent de la maladie de la glande digestive de Ostrea edulis Linne. Sci Peche, Bull Inst Peches Marit 240:7-30

Ko YT, Ford SE, Fong D (1995) Characterisation of the small subunit ribosomal RNA gene of the oyster parasite Haplosporidium costale. Mol Mar Biol Biotech 4(3):236-240

Lewis PR, Knight DP (1977) Staining methods for sectioned material. North-Holland Publishing Company, Amsterdam

Perkins FO (1976) Ultrastructure of sporulation in the European flat oyster pathogen Marteilia refringens-taxonomic implications. J Protozool 23(1):64-74

Perkins FO (1979) Cell structure of shellfish pathogens and hyperparasites in the genera Minchinia, Urosporidium,

Editorial responsibility: Albert Sparks,

Seattle, Washington, USA
Haplosporidium and Marteilia-taxonomic implications. Mar Fish Rev 41(1-2):25-37

Perkins FO, Wolf PH (1976) Fine structure of Marteilia sydneyi sp. n.-Haplosporidian pathogen of Australian oysters. J Parasitol 62(4):528-538

Philippe H, Adouette A (1995) How reliable is our current view of eukaryotic phylogeny? In: Brugerolle G, Mignot JP (eds) Protistological actualities. Proceedings of the Second European Congress of Protistology, ClermontFerrand 1995. Université de Clermont-Ferrand, p 17-33

Robledo JAF, Figueras A (1995) The effects of culture-site, depth, season and stock-source on the prevalence of Marteilia refringens in cultured mussels (Mytilus galloprovincialis Lmk.) from Galicia, Spain. J Parasit 81(3): 354-363

Robledo JAF, Miahle E, Figueras A (1995) Purification of several phases of the paraite Marteilia (Protozoa: Ascetospora) from mussels (Mytilus galloprovincialis). In: Stolen JS, Fletcher TC, Smith SA, Zelikoff JT, Kaattari SL, Anderson RS, Söderhäll K, Weeks-Perkins BA (eds) Techniques in fish immunology, 4. Immunology and pathology of aquatic invertebrates. SOS Publications, Fair Haven, NJ, p 117-121

Stokes N, Burreson E (1995) A sensitive and specific DNA probe for the oyster pathogen Haplosporidium nelsoni. J Eukaryot Microbiol 42(4):350-357

Villalba A, Mourelle SG, Lopez MC, Carballal MJ, Azevedo C (1993) Marteiliasis affecting cultured mussels Mytilus galloprovincialis of Galicia (NW Spain). I. Etiology, phases of the infection, and temporal and spatial variability in prevalence. Dis Aquat Org 16:61-72

Submitted: February 21, 2000; Accepted: November 6, 2000 Proofs received from author(s): February 12, 2001 